удК 330.3:330.16

\title{
СУЧАСНА ІННОВАЦІЙНА ЕКОНОМІКА: ВІД ПІРАМІДИ МАСЛОУ ДО ГЛОБАЛЬНОЇ КОНКУРЕНТОСПРОМОЖНОСТІ КРАЇНИ
}

\section{MODERN INNOVATIVE ECONOMY: FROM THE MASLOW'S PYRAMID TO THE GLOBAL COMPETITIVENESS OF THE COUNTRY}

\author{
Соколова Людмила Василівна \\ доктор економічних наук, профресор, \\ Харківський національний університет радіоелектроніки \\ ORCID: https://orcid.org/0000-0001-8106-1523 \\ Іванова Вікторія Борисівна \\ старший викладач, \\ Харківський національний університет радіоелектроніки \\ ORCID: https://orcid.org/0000-0002-7936-2295 \\ Верясова Ганна Миколаївна \\ старший викладач, \\ Харківський національний університет радіоелектроніки \\ ORCID: https://orcid.org/0000-0002-5287-9833
}

\author{
Sokolova Liudmyla, Ivanova Viktoriia, Veriasova Ganna \\ Kharkiv National University of Radio Electronics
}

\begin{abstract}
У статті розглянуто основні характерні риси інноваційної економіки. Виявлено, що ключовим елементом у структурі сучасної, розвинутої та конкурентоспроможної економіки є людина, яка здатна творити та створювати. Така людина повинна мати не тільки природні здібності та високий рівень свідомості, але й знаходитися в певних умовах (рівень життя, доходів, безпеки тощо), які, безумовно, повинні створюватися на рівні держави. На підставі проведених досліджень запропоновано авторську схему, яка визначає місце та роль людини в структурі сучасної інноваційної економіки. За результатами аналізу ТОП-10 країн-лідерів світу за чотирма глобальними індексами (Індекс глобальної конкурентоспроможності, Глобальний індекс інновацій, Світовий рейтинг добробуту, Індекс глобальної конкурентоспроможності талантів) за три роки виявлено, що існує взаємозв'язок між добробутом життя населення, продуктивністю талантів та, як наслідок, конкурентоспроможністю економіки країни в цілому.

Ключові слова: інноваційна економіка, піраміда Маслоу, мотивація, інноваційна піраміда, глобальні індекси, конкурентоспроможність країни.
\end{abstract}

В статье рассмотрены основные характерные черты инновационной экономики. Выявлено, что ключевым элементом в структуре современной, развитой и конкурентоспособной экономики является человек, который способен творить и создавать. Такой человек должен иметь не только природные способности и высокий уровень осознанности, но и находиться в определенных условиях (уровень жизни, доходов, безопасности и т.д.), которые, безусловно, должны создаваться на уровне государства. На основании проведенных исследований предложена авторская схема, которая определяет место и роль человека в структуре современной инновационной экономики. По результатам анализа ТОП-10 стран-лидеров мира по четырем глобальными индексами (Индекс глобальной конкурентоспособности, Глобальный индекс инноваций, Мировой рейтинг благосостояния, Индекс глобальной конкурентоспособности талантов) за три года выявлено, что существует взаимосвязь между благосостоянием жизни населения, производительностью талантов и, как следствие, конкурентоспособностью экономики страны в целом.

Ключевые слова: инновационная экономика, пирамида Маслоу, мотивация, инновационная пирамида, глобальные индексы, конкурентоспособность страны. 
The article highlights the main features of modern innovation economy, which are based on the discourse and narratives of the theory of two pyramids that form a person with an innovative type of thinking. Based on the analysis of scientific achievements on the problem of research it was found that a significant place is given to human capital in solving the issue of the country's innovative economy development. However, determining the role of innovative and active person at the macro level and its impact on the formation of international competitive advantages of the country is insufficiently studied. Therefore, the aim of the article is to identify the link between the development of the innovative economy of the country as a whole and the personal motivation to create a new product (product, technology or service). It is established that the development of the country's innovative economy at the present stage is not only to create institutional conditions at the state level, but also, first of all, to educate people in a special type of thinking and desire to create and create. It is proved that such a person must have not only natural abilities and a high level of consciousness, but also be in favorable conditions of his life, the creation of which is a more important task of every country. Creativity of: thinking, behavior, life of an innovative and active person currently forms a vector of sustainable development of both the modern economy and the economy of the future. The author's scheme which defines a place and a role of the person in structure of modern innovative economy is offered in the article. According to the results of the analysis of the TOP-10 leading countries in the world on four global indices - national competitiveness, innovation, welfare, competitiveness of talent for three years, it was found that there is a relationship between welfare of nation life, talent productivity and, consequently, competitiveness of the country's economy as a whole. The modern VUCA-world is characterized by unpredictability of economic conditions, conditions of education, conditions of functioning of markets for goods that are constantly changing. This determines the paradigm of professional significance of the quality of person development, namely its innovation, mobility, speed of adaptation, fresh vision, novelty, non-standard solutions, atypical creative actions. In the era of globalization of the economy, dynamism and interdependence of processes, in the development and implementation of new technologies and innovations, new thinking and a new attitude to the current changes, the direction of further research is to conduct a deeper analysis to identify those structural elements of socio-economic sphere in the country, which will form the basis for the growth of a new innovative and active generation in the future.

Keywords: innovation economy, Maslow's pyramid, motivation, innovation pyramid, global indices, country's competitiveness.

Постановка проблеми. В умовах обмеження та вичерпності природних ресурсів проблема пошуку альтернативних методів та способів виробництва $€$ актуальною для країн всього світу. Підґрунтям для вирішення цих проблем $€$ інновації.

Інноваційна економіка (економіка знань) це підвид економіки, в якій основну роль відіграють знання, спостерігається закономірний процес акумулювання ідеї з подальшим перевтіленням в інновації в усіх сорерах людської діяльності, що зумовлює зростання наукомісткого сектора, підвищення продуктивності праці, зменшення матеріальних витрат виробництва, його енергомісткості та робочої сили [1]. Тобто на перше місце в структурі такої економіки виходить людина, яка прагне постійно розвиватися, отримувати нові знання та навички, має здібності генерувати ідеї та можливості втілювати їх в життя. Але постає питання, як зробити так, щоб таких людей було якнайбільше, які умови та механізми для цього потрібні та яку роль така людина відіграє в фрормуванні конкурентоспроможності країни на світовій арені?

Аналіз останніх досліджень та публікацій. Питанням розвитку та розбудови інноваційної економіки країни та значній ролі людського капіталу в цьому процесі присвячені роботи таких авторів, як Л.І. Яковенко [2], В.І. Захарченко [3], Н.М. Краус [4], О.Ю. Чубукова [5],
А.А. Антохов [6], В.А. Ковальчук [7], Г.О. Кундєєва [8], Т.В. Мацибора [9], Ю.Ю. Точиліна [10], Т.В. Поснова [11], O.І. Сахненко [12] та ін.

Виділення невирішених раніше частин загальної проблеми. Незважаючи на підвищений інтерес з боку науковців до проблематики розвитку та розбудови інноваційної економіки, дослідження цього питання не втрачає своєї актуальності. У більшості публікацій значна увага приділяється впливу людського капіталу на фрормування інноваційної активності підприємств, для яких прибуток створюється через особистісні інтелектуальні знання та здібності новаторів. Тобто процес розглядається на мікрорівні. Визначення ролі інноваційноактивної людини на макрорівні та її вплив на формування міжнародних конкурентних переваг країни досліджено недостатньо.

Формулювання цілей статті (постановка завдання). Метою статті $€$ виявлення щільного зв'язку між особистісною мотивацією окремої людини створювати новий продукт (товар, технологію, послугу) та розвитком інноваційної економіки країни в цілому.

Виклад основного матеріалу дослідження. Сучасна економіка - це, поза сумнівом, інноваційна економіка, в якій знання дозволяють генерувати безперервний потік нововведень, що відповідає мінливим динамічним потребам, а досить часто й фрормує 
ці потреби. Знання лише тоді має значення в економічному сенсі, коли воно реалізується у соормі інновацій. Діяльність із виробництва, поширення й використання знань у сучасній економіці відіграє як ніколи важливу роль, визначає її істотні риси і темпи розвитку. Між наукою й технологією виникає нова взаємодія: все більше секторів економіки стають наукомісткими, зростає частка інвестицій у знання, освіту, нематеріальні активи. Мова йде, передусім, про ключову роль людського капіталу, який за певних інституційних умов перетворюється на найважливіший чинник розвитку економічної системи, заснованої на знаннях [2].

Інновації являють собою матеріалізовані наукові та технічні ідеї, які отримали визнання ринку споживачів. Інноваційна діяльність - це не замкнена, обмежена лабораторіями університетів і наукових центрів корпорацій система виробництва нового знання, нових технологій, товарів і послуг, а органічний елемент економічних процесів, що відбуваються в межах національних держав, у галузях господарства, у великих корпораціях і дрібних компаніях. Процес створення знань і винаходів $€$ частиною інноваційної системи, в якій фрундаментальні дослідження, технічний і економічний прогрес взаємопов'язані і взаємозалежні. Шлях від ідеї, фуундаментального відкриття до місця нового продукту на ринку вимагає сприятливого інституційного оточення, в тому числі уваги держави і сильного підприємницького духу у всьому суспільстві. У сучасних умовах, коли знання стають економічним ресурсом, коли інорормаційні технології повністю змінили світове господарство, саме такий підхід до аналізу інноваційної діяльності стає принципово важливим [3].

У вузькому розумінні, інноваційна економіка - це сукупність взаємопов'язаних і взаємодіючих структур (великі та малі підприємства, інкубатори, технопарки, науково-дослідні лабораторії, університети), що зайняті виробництвом і комерціалізацією наукових знань та технологій в межах національних кордонів, взаємодія яких забезпечується комплексом інститутів економічного, соціального й правового характеру та такими, що мають свої традиції, норми та культурні особливості. Дане визначення, в свою чергу, передбачає відповідний спосіб мислення, психологічний настрій індивіда і суспільства, адекватні ментальні моделі, що узгоджені із задекларованою системою правил, незалежно від рівня та способу їх формалізації. У широкому значенні, інноваційну економіку з позиції інституціона- лізму можна тлумачити як економіку з високим рівнем знань та високим духовно-моральним наповненням, в якій суб'єкти господарювання та галузі розвиваються завдяки генерації інноваторами актуальних новацій, які транссоорувалися 3 наукових та фуундаментальних розробок 3 метою отримання надприбутків [4].

Поділяючи наукову думку відносно того, що імператив сучасного розвитку не вимагає особливих пояснень, тому що людина $\epsilon$ і головною умовою, і основним фрактором, і провідним учасником, і користувачем результатів розвитку [13], вважаємо справедливим такий постулат. У центрі інноваційної економіки країни, її провідних секторів - драйверів інноваційного розвитку перебувають системоутворюючі взаємозалежні елементи розвитку - це людина, її знання, вміння та нездоланне прагнення перетворювати світ навколо себе.

Інноваційний розвиток розпочинається з ідеї, яку висуває людина, яка, по-перше, має відповідний рівень освіти, кваліфрікації, мислення; по-друге, спирається на власний нагромаджений досвід і профресіоналізм, проведені наукові дослідження та експериментальну базу, що дає змогу створювати нові знання. Таким чином, виробництво, нагромадження та використання знань $€$ основою інноваційної діяльності в будь-якій сфрері економіки країни. Саме знання стають джерелом збільшення вартості товару або послуги [10].

Отже, якщо в центрі сучасної інноваційної економіки країни знаходиться людина, яка водночас $є$ і виробником, і споживачем інновацій, то процес формування та розвитку економіки будь-якої країни в напрямку стійкого зростання обсягів інновацій та отримання таким чином конкурентних переваг може бути представлений у вигляді рис. 1.

Запропонована схема містить чотири блоки: дві піраміді, блок «Людина 3 інноваційним типом мислення (обізнана, творча)» та блок «Конкурентоспроможність країни». В основі схеми знаходиться відома піраміда А. Маслоу. Такий вибір зумовлений тим, що автори розділяють думку вченого, а саме: «я абсолютно переконаний, що людина живе хлібом єдиним тільки в умовах, коли хліба немає, роз'яснював Маслоу. - Але що трапляється 3 людськими прагненнями, коли хліба вдосталь і шлунок завжди наповнений? 3'являються вищі потреби, і саме вони, а не фрізіологічний голод, керують нашим організмом. У міру задоволення одних потреб виникають інші, все більш і більш високі. Так поступово, крок за кроком людина приходить до потреби в само- 
розвитку - найвищої з них» [14]. Тобто людина починає не тільки діяти більш свідомо, але й осмислювати себе через призму творчості, творення та створення. У даному випадку вважаємо за доцільне виключити з розгляду прояви граничних психологічних станів людини, таких як, наприклад, франатизм, або талант, коли людина просто не в змозі не створювати, не зважаючи на будь-які умови.
Таким чином, фрормується центральний блок - «Людина 3 інноваційним типом мислення (обізнана, творча)», яка, в свою чергу, здатна створювати інновації (рис. 1). Під інновацією в даному випадку слід розуміти процес реалізації інтелектуально-творчого потенціалу людського капіталу через відкриття нових знань та можливостей, втілених у конкретних результатах відповідно до мети інновації [15].

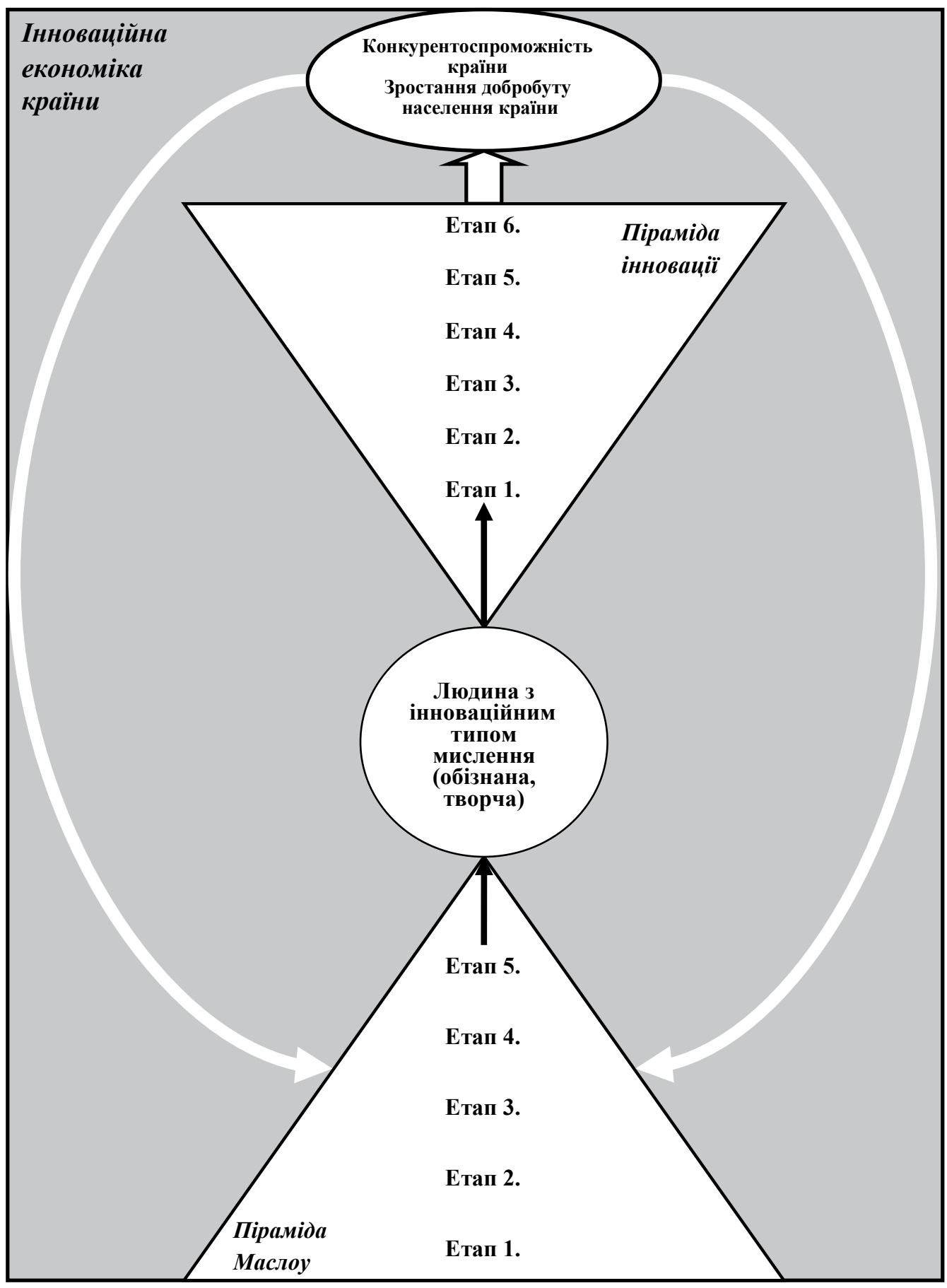

Рис. 1. Схема сучасної інноваційної економіки країни, що структурно визначає місце та роль людини 
Запропонований блок «Піраміда інновації» містить шість основних етапів процесу реалізації інновацій: ідея (генерування, оцінка, відбір), дослідження (проведення і перевірка задуму, розробка стратегії маркетингу), розроблення (створення) прототипу, впровадження (пробний маркетинг), виробництво (розгортання виробництва нової продукції), реалізація (комерційна реалізація як на внутрішньому, так і на міжнародних ринках).

Форму блоку «Піраміда інновації» у вигляді перевернутого трикутника було обрано невипадково. Адже в процесі реалізації інновації виникає цілий спектр взаємозв'язків між різними ссрерами економіки країни, такими як: освіта, ринок праці, виробничі та інорормаційні технології, законодавчі та фрінансові установи, екологічні вимоги тощо. Тобто з'являється ефрект дисперсії світла в призмі, коли завдяки дисперсії біле світло можна розкласти в спектр за допомогою призми. Так само інновація, проходячи через «людину-призму», розкривається спектром низки взаємодій та взаємозв'язків.

У контексті розглянутого теоретичного підходу щодо засадничої ролі інноваційно-активних членів суспільства у розвитку інноваційної економіки країни вважаємо за доцільне розглянути питання, чи дійсно існує взаємозв'язок між добробутом населення, його талановитістю, рівнем інноваційної активності та конкурентоспроможністю країни в цілому.

Для подальшого аналізу було обрано чотири глобальні індекси, які, на думку авторів, в найбільшій мірі можуть розкрити зміст процесу фрормування сучасної інноваційної економіки i, як наслідок, створити відповідні конкурентні переваги країни на міжнародному рівні. В табл. 1 представлено ТОП-10 країн світу за наступними показниками: Індекс глобальної конкурентоспроможності (The Global Competitiveness Index) [16], Глобальний індекс інновацій (The Global Innovation Index) [17], Світовий рейтинг добробуту (The Legatum Prosperity Index ${ }^{\mathrm{TM}}$ ) [18] та Індекс глобальної конкурентоспроможності талантів (The Global Talent Competitiveness Index) [19] за три роки. Авторами було відібрано саме ці індекси, адже вони містять інфрормацію по найбільшій кількості країн світу. Показники індексів за 2020 рік було виключено з розрахунку через глобальну кризу, спричинену COVID-19. Наслідки впливу цього фрактору на світову економіку, на нашу думку, потребують окремого дослідження.

Виходячи зі структури рис. 1 та концепції, якої дотримуються автори, індекси, представлені в табл. 1, можна поділити на дві групи:
- «базові», до яких віднесено Світовий рейтинг добробуту (The Legatum Prosperity Index ${ }^{\text {TM}) ~ т а ~ І н д е к с ~ г л о б а л ь н о і ̈ ~ к о н к у р е н т о-~}$ спроможності талантів (The Global Talent Competitiveness Index);

- «наслідкові», до яких віднесено Індекс глобальної конкурентоспроможності (The Global Competitiveness Index) та Глобальний індекс інновацій (The Global Innovation Index).

Тоді аналіз даних табл. 1 слід проводити так, як це показано на рис. 2.

Аналіз даних, представлених в табл. 1 та на рис. 2, показав, що лише дві країни стабільно займають лідируючі позиції за чотирма індексами протягом трьох років - це Швейцарія та Швеція. Далі йдуть країни, які 3 тих чи інших причин, втратили свої позиції в одному 3 представлених періодів. Це: Нідерланди, Велика Британія та Фінляндія. Далі йдуть Данія, США, Сінгапур, Німеччина та Норвегія. Рейтинги цих країн найбільш представлені в табл. 1. Особливий інтерес викликає позиція Норвегії, адже ця країна стабільно входить до рейтингу The Global Talent Competitiveness Index та The Legatum Prosperity Index ${ }^{\mathrm{TM}}$, але зовсім не представлена за індексами The Global Innovation Index та The Global Competitiveness Index. Тобто населення країни має потужний потенціал талантів, високий рівень добробуту, але це не призвело до підйому їх інноваційної активності та підвищення конкурентоспроможності країни в цілому. Можливо це спричинено сплеском інноваційної активності в інших країнах світу, таких як Сінгапур, наприклад.

Як зазначає в своїй передмові до щорічного звіту "The Legatum Prosperity Index ${ }^{\mathrm{TM}}$. A tool for transformation. Overview» головний виконавчий директор Legatum Institute Філіпа Клер Страуд, баронеса Страуд: «Наша місія в інституті Легатум полягає у створенні шляхів від бідності до процвітання, зосереджуючись на розумінні того, як створюється та реалізується процвітання. Процвітання тягне за собою набагато більше, ніж багатство: воно сягає за межі фрінансової, політичної та судової сфрери, добробуту та характеру нації - мова йде про створення середовища, де людина може розкрити весь свій потенціал. Нація процвітає лише тоді, коли вона має ефективні установи, відкриту економіку та розширює можливості людей, які є здоровими, освіченими та знаходяться у безпечному середовищі.

Вимірювання національного добробуту $€$ важливим завданням для урядів та тих, хто сплачує податки для утримання цих урядів. 
Таблиця 1

Рейтинг ТОП-10 країн-лідерів світу

\begin{tabular}{|c|c|c|c|c|c|}
\hline 2017 & Країна & 2018 & Країна & 2019 & Країна \\
\hline \multicolumn{6}{|c|}{ The Global Competitiveness Index } \\
\hline 1 & Швейцарія & 1 & Швейцарія & 1 & Сінгапур \\
\hline 2 & Сінгапур & 2 & США & 2 & США \\
\hline 3 & США & 3 & Сінгапур & 3 & Гонконг \\
\hline 4 & Нідерланди & 4 & Нідерланди & 4 & Нідерланди \\
\hline 5 & Німеччина & 5 & Німеччина & 5 & Швейцарія \\
\hline 6 & Швеція & 6 & Гонконг & 6 & Японія \\
\hline 7 & Велика Британія & 7 & Швеція & 7 & Німеччина \\
\hline 8 & Японія & 8 & Велика Британія & 8 & Швеція \\
\hline 9 & Гонконг & 9 & Японія & 9 & Велика Британія \\
\hline 10 & Фінляндія & 10 & Фінляндія & 10 & Данія \\
\hline \multicolumn{6}{|c|}{ The Global Innovation Index } \\
\hline 1 & Швейцарія & 1 & Швейцарія & 1 & Швейцарія \\
\hline 2 & Швеція & 2 & Нідерланди & 2 & Швеція \\
\hline 3 & Нідерланди & 3 & Швеція & 3 & США \\
\hline 4 & США & 4 & Велика Британія & 4 & Нідерланди \\
\hline 5 & Велика Британія & 5 & Сінгапур & 5 & Велика Британія \\
\hline 6 & Данія & 6 & США & 6 & Фінляндія \\
\hline 7 & Сінгапур & 7 & Фінляндія & 7 & Данія \\
\hline 8 & Фінляндія & 8 & Данія & 8 & Сінгапур \\
\hline 9 & Німеччина & 9 & Німеччина & 9 & Німеччина \\
\hline 10 & Ірландія & 10 & Ірландія & 10 & Ізраїль \\
\hline \multicolumn{6}{|c|}{ The Legatum Prosperity Index } \\
\hline 1 & Норвегія & 1 & Норвегія & 1 & Данія \\
\hline 2 & Нова Зеландія & 2 & Нова Зеландія & 2 & Норвегія \\
\hline 3 & Фінляндія & 3 & Фінляндія & 3 & Швейцарія \\
\hline 4 & Швейцарія & 4 & Швейцарія & 4 & Швеція \\
\hline 5 & Швеція & 5 & Данія & 5 & Фінляндія \\
\hline 6 & Нідерланди & 6 & Швеція & 6 & Нідерланди \\
\hline 7 & Данія & 7 & Велика Британія & 7 & Нова Зеландія \\
\hline 8 & Канада & 8 & Канада & 8 & Німеччина \\
\hline 9 & Австралія & 9 & Нідерланди & 9 & Люксембург \\
\hline 10 & Велика Британія & 10 & Ірландія & 10 & Ісландія \\
\hline \multicolumn{6}{|c|}{ The Global Talent Competitiveness Index } \\
\hline 1 & Швейцарія & 1 & Швейцарія & 1 & Швейцарія \\
\hline 2 & Сінгапур & 2 & Сінгапур & 2 & Сінгапур \\
\hline 3 & Велика Британія & 3 & США & 3 & США \\
\hline 4 & США & 4 & Норвегія & 4 & Норвегія \\
\hline 5 & Швеція & 5 & Швеція & 5 & Данія \\
\hline 6 & Австралія & 6 & Фінляндія & 6 & Фінляндія \\
\hline 7 & Люксембург & 7 & Данія & 7 & Швеція \\
\hline 8 & Данія & 8 & Велика Британія & 8 & Нідерланди \\
\hline 9 & Фінляндія & 9 & Нідерланди & 9 & Велика Британія \\
\hline 10 & Норвегія & 10 & Люксембург & 10 & Люксембург \\
\hline
\end{tabular}




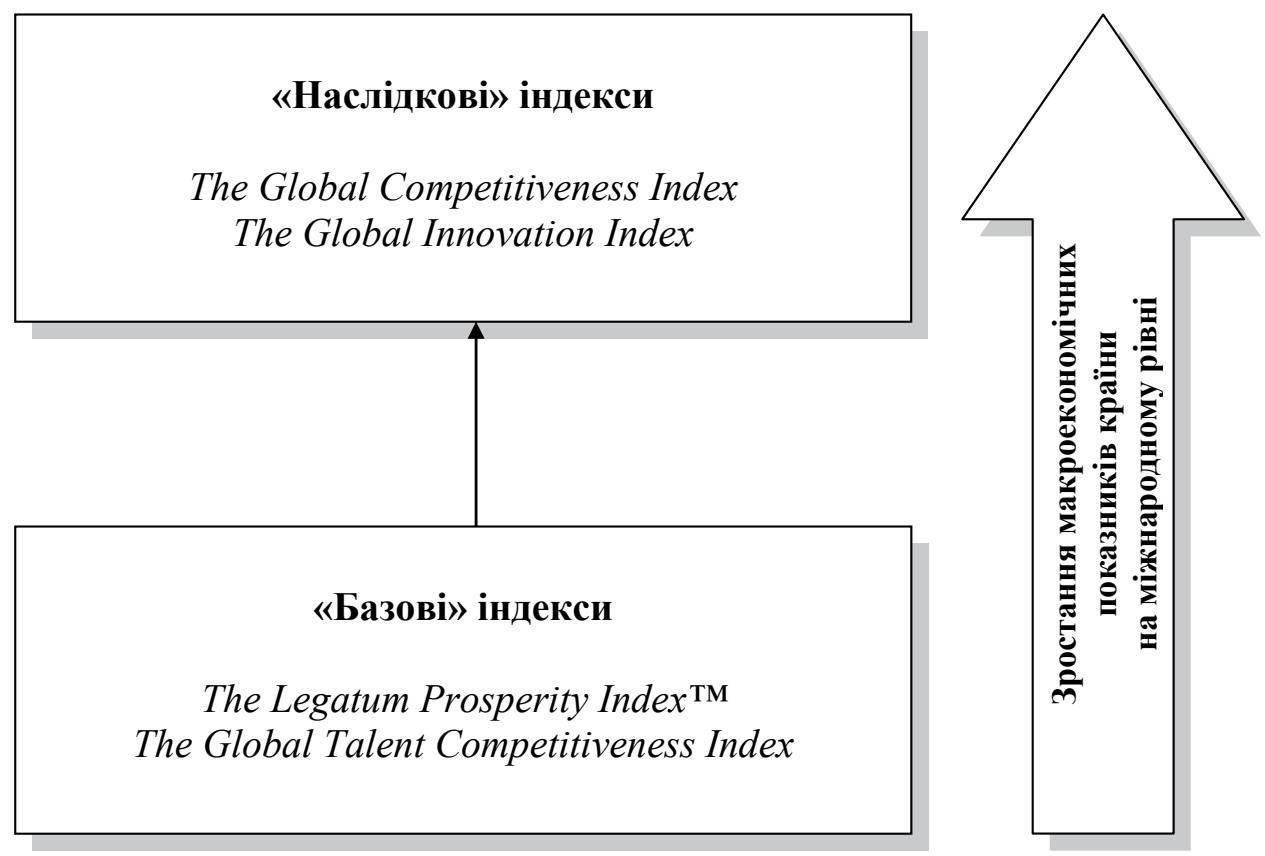

Рис. 2. Схема аналізу «базових» та «наслідкових» індексів

Джерело: авторська розробка

Це реальна міра того, чи справді нація реалізує потенціал свого народу як його виробничої здатності, так і колективного добробуту» [20].

Ален Дехаз, головний виконавчий директор «The Adecco Group» за результатами дослідження «The Global Talent Competitiveness Index (GTCl). 2019. Entrepreneurial Talent and Global Competitiveness» наголошує, що: «...нам потрібно пройти певний шлях перед тим, як всі світові економіки зможуть реалізувати свій справжній потенціал, завдяки конкурентоспроможності талантів. Залишається сильним взаємозв'язок між доходом на душу населення та продуктивністю талантів. Озираючись на середньострокову перспективу, п'ятирічний аналіз GTCI натякає на можливе та тривожне збільшення нерівності конкурентоспроможності талантів. Розрив у талантах між країнами з вищими та нижчими доходами зросла останні кілька років» [21].

Вищезазначені висновки підтверджують концепцію авторів про те, що без стабільного добробуту, піклування про кожну окрему людину, створення державою розбудованої інсрраструктури та сприятливого для розкриття конкурентного потенціалу кожної людини загального клімату в країні інноваційний розвиток неможливий.

Отже, розвиток інноваційної економіки країни на сучасному етапі полягає не тільки в створенні інституційних умов на рівні держави, але й, насамперед, у вихованні в людині особливого типу мислення та бажання творити та створювати нове. Тобто акцент треба робити на сореру освіти та творчості. Адже кожна окрема людина повинна бути вмотивованою на самореалізацію, мати змогу реалізувати свій творчий потенціал, відчувати всебічну підтримку суспільства та держави, а також усвідомлювати свій особистий внесок як у добробут всієї країни, так і підвищення ії конкурентоспроможності.

Висновки. Було установлено, що розвиток інноваційної економіки країни на сучасному етапі полягає не тільки в створенні інституційних умов на рівні держави, але й, насамперед, у вихованні в людині особливого типу мислення та бажання творити та створювати нове, тобто акцент треба робити на ссреру освіти та творчості. Виявлення існування щільного зв'язку між особистісною мотивацією окремої людини створювати новий продукт та розвитком інноваційної економіки країни в цілому дозволяє вважати, що підвищення рівня конкурентоспроможності країни повинно базуватися на розробці ефективної системи підтримки інноваційної активності людей та впровадженні інноваційної концепції розвитку суспільства. Подальші дослідження в цьому напряму дозволять більш глибоко проаналізувати, які саме структурні елементи як економічної, так і соціальної сфер створять базис для формування нового інноваційноактивного покоління в майбутньому. 


\section{СПИСОК ВИКОРИСТАНИХ ДЖЕРЕЛ:}

1. Шевчук С.В. Визначення поняття інноваційна економіка. Формування ринкових відносин в Україні. 2011. № 1. C. 83-86. URL: http://nbuv.gov.ua/UJRN/frvu_2011_1_21

2. Яковенко Л.І. Інноваційний характер економіки знань. Вісник Полтавської державної аграрної академії. 2010. № 2. C. 141-145. URL: https://www.pdaa.edu.ua/sites/default/files/visnyk/2010/02/141.pdf

3. Захарченко B.I. Інновації та економічне зростання в сучасній економіці. URL: https://economics.opu.ua/ files/scientific-base/monogr/maslennikov_mon.pdf

4. Краус Н.М. Інноваційна економіка: десрініція поняття та інституціональний базис розвитку. URL: https://economics-msu.com.ua/web/uploads/journals_pdf/2-4-1-2015.pdf\#page=36

5. Чубукова О.Ю. Складові інноваційної економіки - освіта, технологічні уклади, когнітивні технології. Науковий вісник Полісся. 2016. № 3(7). С. 130-133. URL: https://er.knutd.edu.ua/bitstream/123456789/6213/1/ 20170511_307.pdf

6. Антохов А.А. Взаємовпливи людського капіталу та інноваційного розвитку економіки. Науково-виробничий журнал «Бізнес-навігатор». 2018. Випуск 1-2(44). С. 32-35. URL: http://business-navigator.ks.ua/ journals/2018/44_2_2018/07.pdf

7. Ковальчук В., Шахно А. Інвестування в людський капітал як фрактор інноваційного розвитку економіки України. Сочіально-економічні проблеми і держава. 2016. Вип. 2(15). С. 33-40. URL: https://sepd.tntu.edu.ua/ images/stories/pdf/2016/16kvareu_002.pdf

8. Кундєєва Г.О., Решетник Н.І., Хусаінов Р.В. Людський капітал в контексті інноваційного розвитку економіки України. URL: http://www.investplan.com.ua/pdf/24_2013/10.pdf

9. Мацибора Т.В. Інвестиції в людський капітал як умова розвитку інноваційної економіки. Економіка АПК. 2016. № 12. C. 69-75. URL: http://eapk.org.ua/sites/default/files/eapk/2016/12/e_apk_2016_12_12.pdf

10.Точиліна Ю.Ю. Роль людського капіталу в інноваційному розвитку національної економіки. Науковий вісник Ужгородського національного університету. 2019. Випуск 26. Частина 2. С. 88-91. URL: http://www.visnyk-econom.uzhnu.uz.ua/archive/26_2_2019ua/18.pdf

11. Поснова Т.В. Креативний людський капітал як чинник інноваційного розвитку економіки. Економічний простір. 2019. № 141. С. 172-182. URL: http://prostir.pdaba.dp.ua/index.php/journal/article/view/19/18

12. Сахненко О.I. Вплив відтворення людського капіталу на інноваційний розвиток суспільства. URL: http://www.economy.nayka.com.ua/?op=1\&z=5613

13.Ярмак О.В. Інноваційний розвиток: особливості та виміри в умовах економічної глобалізації. Вісник Національного університету «Юридична академія України імені Ярослава Мудрого». Сер. : Економічна теорія та право. 2014. № 2. C. 118-126. URL: http://econtlaw.nlu.edu.ua/wp-content/uploads/2015/12/ 2-118-126.pdf

14. Пирамида потребностей по Маслоу. Википедия. URL: https://ru.wikipedia.org/wiki/Пирамида_потребностей_по_Маслоу

15. Іванова В.Б. Дослідження френомену життєвого циклу інновації як просторово-часового континууму. Економічний вісник Запорізької державної інженерної академії. Запоріжжя : Запорізька державна інженерна академія. 2017. Вип. 5(11). Частина 1. С. 134-138.

16. The Global Competitiveness Index. URL: https://gtmarket.ru/ratings/global-competitiveness-index

17. The Global Innovation Index. WIPO. Всемирная организация интеллектуальной собственности. URL: https://www.wipo.int/portal/rul

18. The Legatum Prosperity Index TM. URL: https://li.com/reports/

19. The Global Talent Competitiveness Index. URL: https://gtcistudy.com

20. The Legatum Prosperity Index ${ }^{\mathrm{TM}}$. A tool for transformation. Overview. URL: https://li.com/reports/2018legatum-prosperity-index/

21. The Global Talent Competitiveness Index (GTCl). 2019. Entrepreneurial Talent and Global Competitiveness. URL: https://gtcistudy.com/wp-content/uploads/2019/01/GTCl-2019-Report.pdf

\section{REFERENCES:}

1. Shevchuk, S.V. (2011). Vyznachennia poniattia innovatsiina ekonomika [Definition of the concept of innovative economy]. Formuvannia rynkovykh vidnosyn v Ukraini - Market Relations Development in Ukraine, no. 1, 83-86. URL: http://nbuv.gov.ua/UJRN/frvu_2011_1_21 (in Ukrainian)

2. Yakovenko, L.I. (2010). Innovatsiinyi kharakter ekonomiky znan [Innovative nature of the knowledge economy]. Visnyk Poltavskoi derzhavnoi ahrarnoi akademii - Bulletin of Poltava State Agrarian Academy, no. 2, 141-145. URL: https://www.pdaa.edu.ua/sites/default/files/visnyk/2010/02/141.pdf (in Ukrainian) 
3. Zakharchenko, V.I. (2016). Innovatsii ta ekonomichne zrostannia v suchasnii ekonomitsi [Innovation and economic growth in the modern economy]. URL: https://economics.opu.ua/files/scientific-base/monogr/maslennikov_ mon.pdf (in Ukrainian)

4. Kraus, N. (2015). Innovatsiina ekonomika: definitsiia poniattia ta instytutsionalnyi bazys rozvytku [Innovative economy: definition of concept and institutional basis of development]. URL: https://economics-msu.com.ua/web/ uploads/journals_pdf/2-4-1-2015.pdf\#page=36 (in Ukrainian)

5. Chubukova, O.Yu., \& Rallie, N.V. (2016). Skladovi innovatsiinoi ekonomiky - osvita, tekhnolohichni uklady, kohnityvni tekhnolohii [Components of innovative economy - education, technological way, cognitive technologies]. Naukovyi visnyk Polissia - Scientific bulletin of Polissia, no. 3(7), 130-133. URL: https://er.knutd.edu.ua/bitstr eam/123456789/6213/1/20170511_307.pdf (in Ukrainian)

6. Antohov, A.A. (2018). Vzaiemovplyvy liudskoho kapitalu ta innovatsiinoho rozvytku ekonomiky [Interaction human capital and innovative development of the economy]. Naukovo-vyrobnychyi zhurnal «Biznes-navihator»Scientific and practical journal «Business Navigator», no. 1-2(44), 32-35. URL: http://business-navigator.ks.ua/ journals/2018/44_2_2018/07.pdf (in Ukrainian)

7. Kovalchuk, V., \& Shakhno A. (2016). Investuvannia v liudskyi kapital yak faktor innovatsiinoho rozvytku ekonomiky Ukrainy [Investment in human capital as a factor of innovative development of Ukraine's economy]. Sotsialno-ekonomichni problemy i derzhava - Socio-Economic Problems and the State, 15(2), 33-40. URL: https://sepd.tntu.edu.ua/images/stories/pdf/ 2016/16kvareu_002.pdf (in Ukrainian)

8. Kundieieva, G., Reshetnik, N., \& Khusainov, R. (2013). Liudskyi kapital v konteksti innovatsiinoho rozvytku ekonomiky Ukrainy [Human capital in the context of innovative development of ukrainian economy]. URL: http://www.investplan.com.ua/pdf/24_2013/10.pdf (in Ukrainian)

9. Matsybora, T.V. (2016). Investytsii v liudskyi kapital yak umova rozvytku innovatsiinoi ekonomiky [Investment in human capital as the condition of innovation development of economy]. Mizhnarodnyi naukovo-vyrobnychyi zhurnal «Ekonomika APK» - International Scientific and Production Journal «The Economy of Agro-Industrial Complex», no. 12, 69-75. URL: http://eapk.org.ua/sites/default/files/eapk/2016/12/e_apk_2016_12_12.pdf (in Ukrainian)

10. Tochylina, Yuliya (2019). Rol liudskoho kapitalu $v$ innovatsiinomu rozvytku natsionalnoi ekonomiky [The role of human capital in innovation development of the national economy]. Naukovyi visnyk Uzhhorodskoho natsionalnoho universytetu - Scientific Bulletin of Uzhhorod University, no. 26(2), 88-91. URL: http://www.visnyk-econom.uzhnu.uz.ua/archive/26_2_2019ua/18.pdf (in Ukrainian)

11.Posnova, T. (2019). Kreatyvnyi liudskyi kapital yak chynnyk innovatsiinoho rozvytku ekonomiky [Creative human capital as factor of innovative development of economy]. Ekonomichnyi prostir - Economic scope, no. 141, 172-182. URL: http://prostir.pdaba.dp.ua/index.php/journal/article/ view/19/18 (in Ukrainian)

12. Sakhnenko, O.I. (2016). Vplyv vidtvorennia liudskoho kapitalu na innovatsiinyi rozvytok suspilstva [The influence of reproduction of human capital on innovative development of society]. URL: http://www.economy.nayka.com.ual ?op=1\&z=5613 (in Ukrainian)

13. Yarmak, O.V. (2014). Innovatsiinyi rozvytok: osoblyvosti ta vymiry v umovakh ekonomichnoi hlobalizatsii [Innovative development: features and criteria in the conditions of economic globalization]. Visnyk Natsionalnoho universytetu «lurydychna akademiia Ukrainy imeni Yaroslava Mudroho». Ser.: Ekonomichna teoriia ta pravo - The Bulletin of Yaroslav Mudryi National Law University. Series: Economics, no. 2, 118-126. URL: http://econtlaw.nlu.edu.ual wp-content/uploads/2015/12/2-118-126.pdf (in Ukrainian)

14. Pyramyda potrebnostei po Maslou [Maslow's hierarchy of needs]. Wikipedia. URL: https://ru.wikipedia.org/ wiki/Пирамида_потребностей_по_Маслоу

15. Ivanova, V.B. (2017). Doslidzhennia fenomenu zhyttievoho tsyklu innovatsii yak prostorovo-chasovoho kontynuumu [Investigation the phenomenon of the life cycle of innovation as a space-time continuum]. Ekonomichnyi visnyk Zaporizkoi derzhavnoi inzhenernoi akademii - Economic Bulletin of Zaporizhzhia State Engineering Academy, no. 5(11), 134-138. (in Ukrainian)

16. The Global Competitiveness Index. URL: https://gtmarket.ru/ratings/global-competitiveness-index

17. The Global Innovation Index. WIPO. Всемирная организация интеллектуальной собственности. URL: https://www.wipo.int/portal/ru/

18. The Legatum Prosperity Index ${ }^{\mathrm{TM}}$. URL: https://li.com/reports/

19. The Global Talent Competitiveness Index. URL: https://gtcistudy.com

20. The Legatum Prosperity Index ${ }^{\mathrm{TM}}$. A tool for transformation. Overview. URL: https://li.com/reports/2018-legatum-prosperity-index/

21. The Global Talent Competitiveness Index (GTCI) (2019). Entrepreneurial Talent and Global Competitiveness. URL: https://gtcistudy.com/wp-content/uploads/2019/01/GTCl-2019-Report.pdf 